\title{
МУЗИЧНА ІКОНОГРАФІЯ В ДЕКОРІ ЛЬВІВСЬКОЇ АРХІТЕКТУРИ КІНЦЯ XIX - ПОЧАТКУ XX СТ.: МЕТОДОЛОГІЧНИЙ АСПЕКТ
}

\section{- Великанич Софрія Романівна}

- Аспірантка, ORCID: 0000-0003-0896-7171, e-mail: sofia_music@ukr.net, Національна музична академія ім. П. І. Чайковського, вул. Архітектора Городецького, 1-3/11, Київ, Україна, 01001

\section{- Для цитування:}

Великанич, С.Р. (2021). Музична іконографрія в декорі львівської архітектури кінця XIX - початку XX ст.: Методологічний аспект. Питання культурології, (37), 21-32. doi: https://doi. org/10.31866/2410-1311.37.2021.235994.

\section{Анотація}

Мета статті - створити універсальну методологічну систему для досліджень музичної іконографіії в оздобі архітектурних споруд, застосовуючи типологію артефрактів. Резюмувати існуючі наукові надбання в даній галузі та, враховуючи особливості вузькоспеціалізованої теми, інтегрувати їх у контекст культурологічного дискурсу. Опираючись на типологію артефрактів, як основний інструмент у науково-пошуковому процесі, формується схема дослідження в контексті культурологічного дискурсу. Проводиться огляд існуючих розвідок по даній тематиці, а також акцентується увага на необхідності розвитку музичної іконографії як галузі в українському науковому просторі. Враховуючи той факт, що дана стаття спрямована на створення моделі методології для тем конкретного характеру, зазначимо інструменти, які були задіяні в даному процесі: поперше, це типологія артефактів за різними критеріями, як ключового чинника організації матеріалу для аналізу; по-друге, визначення показників, які враховуючи історикокультурний контекст, розширять результати типології і дозволять впевнено інтегрувати ії в русло культурології як науки. Важливо, що створена методологічна система може стати актуальною для роботи з темами, пов'язаними з кількома мистецькими галузями: музикою, архітектурою, скульптурою, а також у дослідженнях, які вивчають місто як мистецький продукт. Інтегративна природа теми потребує такого ж підходу, тому при виборі методологічних інструментів надважливим $€$ враховувати природу галузей, що поєднуються тією мірою, наскільки це дозволяє професійна компетенція дослідникакультуролога. Наукова новизна полягає у здійсненні спроби створити методологічну систему, актуальну для досліджень, пов'язаних з музичною іконографією в декорі архітектурних споруд. Висновки. Наукова робота з темами, які мають міждисциплінарний характер вимагає детального опрацювання варіантів методологічного інструментарію. У кожному конкретному випадку вибір методів може бути продиктованим нахилом в одне, 
або інше наукове русло. Саме тому створення методологічної системи для дослідження теми музичної іконографії в декорі архітектури в контексті культурології є необхідним для логічного розгортання наукового пошуку.

Ключові слова: музична іконографія; типологія; методологія

\section{Вступ}

В процесі вибору методологічної системи для дослідження необхідно враховувати ряд стратегічно важливих моментів, нехтування якими може вплинути не лише на вдале протікання наукових пошуків, а й на їх результати. У випадку із дослідженням музичної іконографії в декорі архітектурних споруд у Львові в період кінця XIX - початку XX ст. підхід повинен мати комплексний характер і враховувати ще і культурологічне спрямування роботи. Тема окреслює вузькоспеціалізований вектор і потребує індивідуального підходу. У зв'язку з цим ми плануємо проаналізувати існуючі напрацювання у сфері іконографрії і використати актуальні для власного дослідження засади; здійснити типологію виявлених артефрактів музичної іконографії для систематизації предметів для аналізу, а також узагальнити і сформувати концентровану робочу схему для інтеграції виявлених зразків в науковий контекст. Крім того, як допоміжні показники застосувати чинники культурного середовища, які дозволять розширити можливості дослідження, а також впевнено зафріксувати його в межах культурологічного дискурсу.

Актуальність дослідження полягає у створенні методології, яка тією, чи іншою мірою може бути використана для роботи з темами, пов'язаними з музикою, архітектурою, скульптурою, а також у дослідженнях міста як мистецького фракту. Інтегративна природа теми музичної іконографії в декорі архітектури потребує такого ж підходу, тому створення методологічних інструментів для дослідження вузькоспеціалізованого аспекту є актуальним науковим завданням.

Музична іконографрія як галузь гуманітарних наук в Україні, на жаль, ще не достатньо реалізувала свій потенціал. Але, відомо, що у працях фахівців з Австрії, Німеччини, Польщі, Росії, США, Франції ця тематика широко розробляється і має потужний дослідницький фундамент. Прикладами є дослідження зразків сакральної архітектури М. Єсіповою (Есипова, 2014) «Сокровенні смисли музичної іконографії кіотського храму Сандзю: сангендо», численні мистецтвознавчі дослідження музичної іконографії А. Майкапара (офріційний сайт А. Майкапара: https://www.maykapar.com/), а також стаття М. Стоклі (Stöckli, 2009) «Музична іконографрія» про зразки музичної іконографії в межах культури племен Мая. Серед українських науковців можемо назвати Л. Купчинську (2014) і її статтю «Ференц Ліст на рисунках Юліуша Коссака».

В контексті досліджень Львова варто згадати статтю О. Николин (2004) «Сторінки львівської шопеніани» та ґрунтовні праці Ю. Бірюльова $(2005,2015)$, пов'язані із вивченням сецесії як стилю, де музична символіка в архітектурній оздобі показується лиш як його прояв, а не самостійне і самобутнє явище.

Звісно, існують роботи, які зачіпають музичну складову лише частково, в межах інших галузей науки. Серед них варто назвати роботу І. Тоцької (1995) 
«Музики на малюваннях Софрії Київської» та працю Ю. Бірюльова (2005) «Мистецтво львівської сецесії».

Окрім статей, в заявленій тематиці знаходимо дисертацію Д. Воробйової (Воробьева, 2013) «Іконографія напівбожественних музикантів в скульптурі Аджанти, Еллори, Аурангабада». В українському науковому просторі дисертацій, присвячених музичній іконографрії поки не існує.

Оскільки основним методологічним інструментом в роботі заявлено типологію, зазначимо кілька праць, засади яких було обрано за фундамент у даному питанні. Передусім це праця «Типологія архітектури» І. Синянського та Н. Манешиної (2014), де автори формулюють чітке визначення цього явища.

Крім того, продуктивність типології іконографрічних зображень підтвердив Г. ван де Вааль в 1950 р., створивши «Каталог нідерландського мистецтва» і впорядкувавши його за іконографрічним принципом. Він створив сайт (www.iconclass.nl), де розділив різні види зображень на 9 груп (п'ять основних і чотири додаткових) і наділив їх спеціальними шифрами. Також такі іконографічні картотеки існують в інститутах Утрехта, Лондона та Гамбурга. $€$ окремо опрацьовані типології політичної іконографрії та іконографії конкретних художників (Брейгеля, Сезанна та ін.).

Ще однією працею, яка продуктивно спрацювала у формуванні методології стала «Архітектура міста» А. Россі (Росси, 2015). На думку автора тип - це щось постійне і складне; це логічна конструкція, яка передує формі і створює iї. Тип — первісний, форма - вторинна, а отже, на його основі можна будувати стійку методологічну систему. У випадку з конкретною темою, класифрікація за типами допоможе впорядкувати предметну складову. Крім того, висновки можуть виникати вже на етапі формування груп, оскільки зіставляючи наявні зразки, з'являється розуміння картини загалом. Тобто, в такому випадку типологія $€$ не самоціллю, а лише інструментом у вирішенні завдань дослідження.

А. Россі (Росси, 2015) подає визначення «типу» теоретика архітектури Картмера-де-Кенсі, яке $є$ близьким нам по суті: «слово тип являє собою не скільки образ предмета, який необхідно копіювати чи точно повторювати, скільки ідею елемента, який сам повинен служити правилом для моделі» (с. 76).

В цьому ж руслі працює потужний осередок із вивчення музичної іконографiї - дослідницький центр RCMI (Research Center of Music Iconography) (https:// cutt.ly/pznRMWP) на базі університету CUNY в Нью-Йорку (США). Це наукова спільнота, заснована спеціально для проведення досліджень музичної тематики в художніх творах в 1972 році.

Первісно, RCMI було створено як американський національний центр та штаб-квартиру центру Міжнародного музичного мистецтва Répertoire d'Iconographie (RIdIM), що має на меті створення доступу до джерел музичної іконографрії, колекції фооторепродукцій художніх творів. Цей каталог є єдиним у США, де можна легко знайти візуальні зображення будь-якого інструмента чи музичної сцени від античності до початку XX ст. Даний факт підтверджує також продуктивність типології, як інструменту для роботи з темами подібного типу. 


\section{- Мета статті}

Метою дослідження $є$ створення методологічної системи для роботи із музичною іконографрією в декорі архітектурних споруд з максимально високим рівнем універсальності. Застосовуючи існуючі надбання в даній галузі і інтегруючи їх у контекст власного наукового пошуку, створити комплексну систему в межах культурологічного дискурсу.

\section{- Виклад матеріалу дослідження}

Тема музичної іконографрії в архітектурній оздобі Львова кінця XIX - початку $\mathrm{XX}$ ст. володіє високою мірою наукового потенціалу, оскільки здатна не лише допомогти прослідкувати фракти з реального життя, побуту, звичаїв та традицій, але й розкрити культурні пласти, нашаровані попередніми епохами. Саме тому, на основі такого матеріалу розробляти методологію органічно та продуктивно.

Доволі складно уніфікувати і створити методологічний шаблон, однаково корисний для суміжних тем, оскільки різні історичні періоди та різний аналітичний матеріал вимагає різного підходу. Однак, сформувавши систему на прикладі однієї теми стає більш зрозуміло як адаптувати ії під інші, схожі завдання.

Перше, про що варто говорити в процесі формування методології в такому випадку $є$ загальні маркери, які відповідатимуть за ії культурологічне спрямування. Наукове занурення в історію забудови міста, осмислення актуального контексту епохи, яка завжди має часові межі і характерні риси, розуміння роботи з конкретним видом мистецтва - все це ставить перед дослідником безліч складних завдань, які необхідно вирішувати поступово.

Отже, для початку необхідно конкретизувати механізми типології зразків за різними критеріями для спрощення процесу аналізу і уникнення фактологічного розпорошення. Оскільки артефакти міста містять багатий матеріал для вивчення музичної символіки, сюжетів, інструментарію, персоналій, без наявності системи їх аналіз може втратити логіку і науковий баланс.

В даному контексті приведемо цікаве спостереження видатного дослідника іконографії Е. Панофського: зосереджуючи увагу на певних артефрактах, дослідник, свідомо, чи несвідомо підпорядковується до принципу попереднього відбору, що продиктований загальною історичною концепцією. Дослідникприродознавець мимоволі обирає для аналізу те, що потрібно називати явищем, в той час, як дослідник-гуманітарій обирає те, що потрібно називати історичним фрактом (Торопыгина, 2015, с. 17). Ця думка засвідчує природність походження структуризації аналітичного процесу. У випадку, коли предметна частина дослідження складається із різноманітних по характеристиках артефактів, типологія сприятиме досягненню цілісності і ясності наукових висновків.

На користь продуктивності типології іконографічних зображень свідчать також і конкретні фракти з історії та науки. Згадаємо один із них: видатний дослідник іконографрії А. Варбург створив атлас «Мнемозіна» (дерев'яні панелі, на яких згруповані зображення із історії світового мистецтва), маючи на меті показати алегоричні зображення, які використовували художники епохи Ренесансу і пов'язати їх зі словом, тобто пояснити значення кожного окремого образу. Очевидно, не у всіх випадках алегорію було необхідним пояснювати, особливо для 
сучасників автора, проте така типологія являє собою сконцентрований тезаурус реалізації конкретного образу у різних митців епохи, який несе інфрормацію для нащадків через століття. Даний фракт є ще одним доказом актуальності досліджень іконографрічної спрямованості (Фокеева, 2015).

Окрім типології, в процесі аналізу зразків музичної іконографії продуктивними науковими інструментами можуть стати також атрибуція імен творців представлених споруд, а саме архітекторів, а також скульпторів-декораторів. Також цінним буде виявлення тих чинників, які безпосередньо впливали на створення тих чи інших зразків музичної іконографії. Тут ідеться про історичну ситуацію, моду, індивідуальний стиль, психологічні чинники та інші менш важливі аспекти життя митців, які могли накласти відбиток на результат творчості. Усвідомленість в цьому напрямі може вивести на ряд важливих висновків та узагальнень.

Інфрормація про власників будівель може також допомогти у з'ясуванні цінних подробиць життя і діяльності в конкретній архітектурній споруді. До цієї класифрікаційної ланки відносимо і замовників, якщо інформація про таких є відомою. Цей пункт з погляду реконструкції історії $€$ особливо цінним, оскільки декорування будинків могло бути пов'язаним з професією, чи вподобаннями замовників, а отже, і пояснити причини і суть оздоби. Особливо це стосується житлових будівель, призначення яких явно не розкриває фрактів. Зрозуміло, що вірогідність виявлення таких фрактів $€$ не надто високою, однак при наявності допоміжних даних, аналіз і його результати можуть отримувати «свіжий» погляд.

Цікавим та цінним може стати погляд на споруду в її теперішньому вигляді і з огляду на сучасне функціональне призначення. Трансформація прикладного чинника хоч і не зможе пояснити причини появи музичної іконографії, однак покаже як архітектура минулого існує в сучасності і як з нею співіснує.

Отже, з метою конкретизації зазначеного, назвемо групи, які було сформовано в процесі аналізу музичної іконографії в архітектурному декорі Львова в період кінця XIX - початку XX ст. Було виділено три рівні класифрікації, які отримали внутрішній поділ: фуункціональний (споруди житлового, сакрального, меморіального та спеціального призначення); стильовий (сецесія, історизм, неокласицизм, модерн); жанровий (постаті, музичні сцени, інструменти, мотиви, оздоба храмів, меморіальні об'єкти).

Наголошуємо, що типологія була здійснена лише на основі конкретних віднайдених артефактів і може доповнюватись в міру доповнення новими зразками. Структура типології $є$ доволі універсальною, тому розвиток дослідження в такому руслі має перспективи.

Фундамент, яким для дослідження є вищезазначена типологія потребує доповнення історико-культурним контекстом, тому далі визначимо ключові чинники, які зможуть сприяти реалізації поставлених завдань: реконструкції історії, розкриття причин появи музичної іконографії в оздобі архітектурних споруд і атмосфрери міста загалом.

1. Атрибуція імен архітектора та скульптора-декоратора. Даний пункт ставимо на початку схеми, оскільки в процесі наукової розвідки стало зрозуміло, що в той час особистісний фрактор в містобудуванні був вкрай важливим. Велика 
кількість митців архітектурної справи, які працювали у Львові, свідчить про те, що ті, хто реалізовував власні проєкти на практиці, очевидно, мав беззаперечний авторитет. Крім того, ми розглядаємо скульптурну оздобу та металопластику в аспекті творчого прояву, тому оминати особистості, що їх втілювали було б некоректно. Оскільки акцентом дослідження $є$ скульптурна пластика, особливу увагу приділяємо саме скульпторам.

В даному контексті найяскравішим прикладом реалізації музичної іконографії в скульптурному декорі львівських будівель стала постать 3. Курчинського скульптора польського походження, який, здобувши європейську освіту жив і творив у Львові. В процесі дослідження було виявлено велику кількість локацій, де за створенням музичної іконографії стоїть ім'я Курчинського. Очевидно, таке зацікавлення не може вважатися випадковим. Дослідження причин появи даної тематики в творчості митця зможуть вивести на цінні знахідки як у вивченні біографії скульптора, так і в заявленій темі. Даний приклад демонструє - атрибуція імен творців $є$ важливим науковим кроком у подоланні методологічного шляху.

2. Передумови створення будівлі. Цей пункт не у всіх випадках буде можливим вияснити, та й його значення не завжди буде принциповим. Як-от, наприклад, у випадку з прибутковими (чиншовими) будинками, причини створення яких і так є зрозумілими - їх будували для того, щоб здавати в оренду. Однак зустрічатимуться також і інші будівлі, передумови створення яких можуть допомогти вияснити цінні факти, важливі в контексті теми. В цьому ж пункті може міститись інформація про власників, особливо якщо вони $є$ одночасно і замовниками, оскільки так можна прослідкувати зв'язок оздоби із загальним задумом. Однак, враховуючи історичну віддаленість передбачаємо, що таку інформацію буде можливим віднайти далеко не завжди.

3. Функціональне призначення архітектурної споруди (тоді і зараз). У випадку із будівлями спеціального призначення їх утилітарна функція $є$ зрозумілою, проте оскільки мова йде про період кінця XIX - початку XX ст. у ряді випадків вона може змінитись, чи трансформуватись. Ось, наприклад, будівля Галицького музичного товариства (Чайковського, 7) сьогодні слугує приміщенням фрілармонії та музичного коледжу. Отже, спрямування свого не поміняла, проте суть все ж трансформувалась.

4. Стиль будівлі і її значення в контексті епохи. Даний пункт є доволі цікавим, адже період, що досліджується характеризується широкою палітрою стилів і їх поєднань. Велика кількість митців-оздоблювачів архітектурних споруд, що працювали в той час у Львові втілювали у своїй творчості різноманіття стильових проявів, перебуваючи при цьому в контексті світових тенденцій. До цього пункту відносимо також поняття моди та культурно-історичного часу. Обидва поняття мають колосальний вплив на всі процеси, які відбуваються в культурі загалом, і у визначений період у Львові, зокрема. Перетин і поєднання ментальних особливостей багатонаціонального міста, творча атмосфера, яка в ньому панувала, якнайкраще знайшли відображення в архітектурі та стали причиною довготривалого існування неповторного і науково невловимого «духу міста».

Осмислюючи віднайдені зразки музичної іконографії на спорудах у Львові стає зрозуміло, що стиль є показовим чинником в даному контексті. Класифіку- 
ючи артефакти за стилями визначаємо ті з них, в межах яких музична символіка знайшла свою більш-менш яскраву реалізацію. Конкретизуючи даний факт можемо стверджувати, що сецесія більшою, ніж інші представлені стилі, мірою сприяла реалізації музичної іконографії в декоративній оздобі львівських будинків на зламі століть. Причини і подальше дослідження цих взаємозв'язків може вивести наукові пошуки на новий рівень по даній темі.

5. Жанрова характеристика музичної іконографії. Даний пункт наближає нас до суті наукових пошуків і його результатів. Через жанрові установки матимемо можливість більшою мірою зрозуміти причини появи музичної іконографії, впливи, які спонукали до реалізації символіки такого типу. Саме через жанрову типологію виявляється можливим осмислити, які теми були популярними в той час, а звідси, і корені їх появи.

Зображення музичних інструментів без прив'язки до сюжету, або ж навпаки - яскраві скульптурні зображення, які потребують смислового розшифрування; портрети музикантів, чи декоративні музичні натяки на металопластикових конструкціях - всі ці типи віднайдених зразків несуть різний інформаційний посил, зчитування якого і $є$ основним завданням дослідження. Саме тому, жанрові установки повинні займати в методологічній ієрархії одну із найбільш вагомих позицій.

6. Сучасний стан споруди і відповідність артефрактів музичної іконографрії теперішньому призначенню. Пункт, який підсумовує вище проаналізовані компоненти методології. В даному аспекті важливим $є$ акцент на актуалізацію дослідження загалом, оскільки цінність будь-якої наукової роботи полягає саме в ії зв'язку із сучасністю. Тут також вважаємо за необхідне акцентувати на проблемі збереження культурних пам'яток на державному рівні, адже дбайливе ставлення до спадку (в цьому випадку архітектурного) $€$ індикатором загального рівня культури. Розуміння цінності тих артефактів, що залишили попередні епохи $€$ надважливим у процесі освіти і в повсякденному житті.

Даний пункт $€$ важливим з точки зору культурної спадкоємності. В артефактах, залучених до роботи є зразки будівель, які до сьогодні зберегли своє музичне призначення (Чайковського, 7, проспект Свободи 1/3, Шашкевича, 5), a $€$ i ті, в яких призначення кардинально змінилось. Для історії культури фракти такої спадкоємності є важливими і, в деяких випадках, промовистими. Тому, їх детальне осмислення може вивести на ряд важливих висновків з погляду культури.

Окрім цих основних пунктів в процесі дослідження можуть виникати і побічні - фракти, які, безумовно, доповнять його змістову складову. До таких відомостей можна віднести враження замовників від виконаної роботи, відповідність задуму реальному призначенню споруди та інше.

3 поданої системи може скластись враження, що більшість іїі пунктів спрямовані на будівлю загалом, однак таке рішення $є$ осмисленим і продуманим. Щоб проаналізувати музичну іконографію в скульптурній оздобі чи металопластиці в тому ключі, який відкриває її культурологічне спрямування доводиться враховувати безліч чинників. Виходить, щоб зрозуміти мотиви появи музичної символіки, дослідник повинен через історичні, культурні, особистісні процеси, 
використовуючи дедуктивний метод пізнання наближатись до суті. В цьому і полягає природа культурологічного дослідження із музичним спрямуванням.

Варто зазначити, що в процесі наукових пошуків такого плану велику роль відіграє психологічна складова самого дослідника, оскільки аналіз, який він проводить $€$ інтелектуальним нашаруванням вже існуючого в його свідомості інформаційного досвіду. Перебуваючи протягом тривалого періоду життя в архітектурній атмосфрері міста, дивитись і аналізувати його неупереджено видається просто неможливим. Особисті асоціації, які накопичились разом із життєвим досвідом, створюють природний «плацдарм» для фрормування наукових висновків. І ця ситуація має дві сторони: з одного боку, обізнаність дослідника в трансформаціях міста (як в матеріальному, так і духовному планах) є, безумовно, корисною, з іншого ж, підбивання підсумків, які б відрізнялись «свіжістю» і неупередженістю виявляються не цілком реальними.

Крім того, слід не забувати, що архітектурний об'єкт, який стає предметом аналізу вже апріорі несе відбиток психологічної складової його творців, адже окрім аспектів, які вже згадувались вище (мода, культурна ситуація, призначення) витвір мистецтва завжди нерозривно пов'язаний з особистостями тих, хто його творить і тим рівнем інтелектуального, творчого і соціального досвіду, яким вони його наділяють.

\section{- Висновки}

Враховуючи широку палітру віднайдених артефактів музичної іконографії у Львові, з метою досягнення плідних результатів для аналізу було обрано скульптурну оздобу архітектурних споруд та зразки металопластики в їх контексті. Такий вибір був продиктований саме культурологічним спрямуванням роботи. Зразки, які фрізично доступні до пізнання кожному, хто прогулюється вулицями старовинного міста, у більшості випадків не отримують відгуку у культурній свідомості. Даним дослідженням прагнемо відкрити ті пласти культури, які, на жаль, залишаються прихованими не лише для пересічних глядачів, але й спеціалістів у галузі мистецтвознавства, музикознавства та культурології.

Малодосліджена галузь музичної іконографії потребує розробки методологічного інструментарію для її вивчення. У даній статті відтворено один із можливих варіантів дослідницької системи за допомогою типології артефактів. Вважаємо, що такий метод може не лише показати багатогранність тем і образів, які стосуються музичного мистецтва в скульптурному декорі львівських будинків, а й допомогти дослідникам названих галузей знайти свою ділянку для вивчення такої цікавої та науково нерозвиненої теми.

Очевидно, що дана методологічна система не є досконалою і не до всіх наукових завдань зможе органічно пристосуватись. Наприклад, у разі, коли зображення $є$ шаблонним і повторюється в декількох екземплярах немає сенсу досліджувати мотиви творця, проте цікаво розібратись у сюжеті, який може розкрити важливі аспекти модних тенденцій в архітектурі й мистецтві того часу. Творення методології - процес складний і неоднозначний, однак акцентування на важливих чинниках, які необхідно досліджувати може допомогти визначити пріоритети наукових пошуків. 


\section{- Список використаних джерел}

Бірюльов, Ю. (2005). Мистецтво львівської сецесії. Центр Європи.

Бірюльов, Ю. (2015). Львівська скульптура від раннього класицизму до авангардизму (середина XVIII - середина XX cm.). Апріорі.

Воробьева, Д. (2013). Иконография полубожественных музыкантов в скульптуре Аджанты, Эллоры, Аурангабада [Автореферат диссертации кандидата искусствоведения, Отдел искусства стран Азии и Африки Государственного института искусствознания].

Есипова, М. (2014). Сокровенные смыслы музыкальной иконографии киотского храма Сандзю: сангэндо. Ежегодник Японии. https://cyberleninka.ru/article/n/ sokrovennye-smysly-muzykalnoy-ikonografii-kiotskogo-hrama-sandzyu-sangendo

Купчинська, Л. (2012). Ференц Ліст на рисунках Юліуша Коссака (до 165-ліття перебування Ф. Ліста у Львові). Вісник НТШ. http://ntsh.org/node/300

Николин, О. (1993). Шопеніана у збірках Львова (живопис, графріка, скульптура, фотографрія). Записки Наукового Товариства імені Шевченка. Праці Музикознавчої комісії, 226, 498-504.

Николин, О. (2004). Сторінки львівської шопеніани. Автографи Фридерика Шопена та його сучасників. Записки Наукового Товариства імені Шевченка. Праці Музикознавчої комісії, 247, 402-414.

Росси, А. (2015). Архитектура города (А. Голубцова, Пер.). Стрелка Пресс.

Синянский, И., \& Манешина, Н. (2014). Типология зданий. Академия.

Торопыгина, М. (2015). Иконология. Начало. Проблема символа у Аби Варбурга и в иконологии его круга. Прогресс-Традиция.

Тоцька, І. (1995). Музики на малюваннях Софії Київської. Пам'ятки України, 1, 45-53.

Фокеева, В. П. (2015). Атлас "Мнемозина" Аби Варбурга: память образов. Вестник Московского государственного лингвистического университета. Гуманитарные науки. https://cyberleninka.ru/article/n/atlas-mnemozina-abivarburga-pamyat-obrazov

Stöckli, M. (2009). Musical iconography. http://www.famsi.org/reports/03101/55stockli/55stockli.pdf

\section{- References}

Biriulov, Yu. (2005). Mystetstvo Ivivskoi setsesii [The art of Lviv secession]. Tsentr Yevropy [in Ukrainian].

Biriulov, Yu. (2015). Lvivska skulptura vid rannoho klasytsyzmu do avanhardyzmu (seredyna XVIII - seredyna XX st.) [Lviv sculpture from early classicism to avant-garde (mid-18 $8^{\text {th }}-$ mid-20 $^{\text {th }}$ centuries)]. Apriori [in Ukrainian].

Esipova, M. (2014). Sokrovennye smysly muzykal'noy ikonografii kiotskogo khrama Sandzyu: sangendo [The innermost meanings of the musical iconography of the Kyoto Sanju temple: sangendo]. Ezhegodnik Yaponii. https://cyberleninka.ru/article/n/ sokrovennye-smysly-muzykalnoy-ikonografii-kiotskogo-hrama-sandzyu-sangendo [in Russian].

Fokeeva, V. P. (2015). Atlas "Mnemozina" Abi Varburga: pamyat' obrazov [Atlas «Mnemosyne» by Abi Warburg: memory of images]. Vestnik Moskovskogo gosudarstvennogo lingvisticheskogo universiteta. Gumanitarnye nauki. https://cyberleninka.ru/article/n/ atlas-mnemozina-abi-varburga-pamyat-obrazov [in Russian]. 
Kupchynska, L. (2012). Ferents List na rysunkakh Yuliusha Kossaka (do 165-littia perebuvannia F. Lista u Lvovi) [Ferenc Liszt in drawings by Juliusz Kossak (to the $165^{\text {th }}$ anniversary of F. Liszt's stay in Lviv)]. Visnyk NTSh. http://ntsh.org/node/300 [in Ukrainian].

Nykolyn, O. (1993). Shopeniana u zbirkakh Lvova (zhyvopys, hrafika, skulptura, fotohrafiia) [Chopin in the collections of Lviv (painting, graphics, sculpture, photography)]. Zapysky Naukovoho Tovarystva imeni Shevchenka. Pratsi Muzykoznavchoi komisii, 226, 498-504 [in Ukrainian].

Nykolyn, O. (2004). Storinky Ivivskoi shopeniany. Avtohrafy Fryderyka Shopena ta yoho suchasnykiv [Pages of the Lviv Chopin. Autographs of Frederic Chopin and his contemporaries]. Zapysky Naukovoho Tovarystva imeni Shevchenka. Pratsi Muzykoznavchoi komisii, 247, 402-414 [in Ukrainian].

Rossi, A. (2015). Arkhitektura goroda [City architecture] (A. Golubtsova, Trans.). Strelka Press [in Russian].

Sinyanskiy, I., \& Maneshina, N. (2014). Tipologiya zdaniy [Typology of buildings]. Akademiya [in Russian].

Stöckli, M. (2009). Musical iconography. http://www.famsi.org/reports/03101/55stockli/55stockli.pdf [in English].

Toropygina, M. (2015). Ikonologiya. Nachalo. Problema simvola u Abi Varburga i v ikonologii ego kruga [Iconology. Start. The problem of the symbol in Abi Warburg and in the iconology of his circle]. Progress-Traditsiya [in Russian].

Totska, I. (1995). Muzyky na maliuvanniakh Sofii Kyivskoi [Music on the drawings of Sophia of Kyiv]. Pam'iatky Ukrainy, 1, 45-53 [in Ukrainian].

Vorobyova, D. (2013). Ikonografiya polubozhestvennykh muzykantov v skul'pture Adzhanty, Ellory, Aurangabada [/conography of semi-divine musicians in the sculpture of Ajanta, Ellora, Aurangabad] [Abstract of PhD Dissertation, Otdel iskusstva stran Azii i Afriki Gosudarstvennogo instituta iskusstvoznaniya] [in Russian].

\section{MUSICAL ICONOGRAPHY IN THE DECOR OF LVIV ARCHITECTURE OF THE LATE $19^{\text {TH }}$ EARLY 20 ${ }^{\mathrm{TH}}$ CENTURIES: METHODOLOGICAL ASPECT}

\section{- Sofiia Velykanych}

- PhD student,

ORCID: 0000-0003-0896-7171, e-mail: sofia_music@ukr.net,

Ukrainian National Tchaikovsky Academy of Music,

Kyiv, Ukraine

\section{- Abstract}

The purpose of the article is to create a methodological system to research musical iconography in the decor of architectural structures, based on the typology of the artifact; to overview the existing scientific developments on the topic, taking a cue from the fieldspecific topic, to integrate them into the context of cultural discourse. Based on the typology of artefacts, as the primary tool in the research process, there is a research scheme in the context 
of cultural discourse. The article reviews the existing research on this topic and focuses on the need to develop musical iconography as a branch in the Ukrainian scientific space. Given the fact that this article aims to create a model of methodology for topics of a specific nature, the tools involved in this process as follows: first, it is a typology of artefacts by various criteria, as a critical factor in material order for analysis; secondly, the identification of factors that will take into account the historical and cultural context, expand the results of typology and allow to integrate it into the stream of culturology as a science confidently. It is important that the created methodological system can become relevant for working with topics related to several art fields: music, architecture, sculpture, as well as in studies that research the city as an art product. The integrative nature of the topic requires the same approach, so when choosing methodological tools, it is crucial to consider the nature of the industries that are combined to the extent permitted by the professional competence of the culture researcher. The scientific novelty is an attempt to create a methodological system relevant to research related to musical iconography in the decor of architectural structures. Conclusions. Scientific work with topics that have an interdisciplinary nature requires the detailed elaboration of variants of methodological tools. In each case, the choice of methods may be dictated by the inclination in a scientific direction. That is why creating a methodological system for the study of the theme of musical iconography in architecture in the context of culturology is necessary for the logical development of scientific research.

Keywords: musical iconography; typology; methodology

\section{МУЗЫКАЛЬНАЯ ИКОНОГРАФИЯ В ДЕКОРЕ ЛЬВОВСКОЙ АРХИТЕКТУРЫ КОНЦА ХІХ - НАЧАЛА ХХ ВВ.: МЕТОДОЛОГИЧЕСКИЙ АСПЕКТ}

\section{- Великанич София Романовна}

- Аспирантка,

ORCID: 0000-0003-0896-7171, e-mail: sofia_music@ukr.net, Национальная музыкальная академия Украины им. П. И. Чайковского, Киев, Украина

\section{- Аннотация}

Цель статьи - создать универсальную методологическую систему для исследований музыкальной иконографии в отделке архитектурных сооружений, применяя типологию артефрактов. Резюмировать существующие научные достижения в данной области и, учитывая особенности узкоспециализированной темы, интегрировать их в контекст культурологического дискурса. Опираясь на типологию артефактов, как основной инструмент в научно-поисковом процессе, формируется схема исследования в контексте культурологического дискурса. Проводится обзор существующих работ по данной тематике, а также акцентируется внимание на необходимости развития музыкальной иконографии как отрасли в украинском научном пространстве. Учитывая тот фракт, что данная статья направлена на создание модели методологии для тем 
конкретного характера, отметим инструменты, которые были задействованы в данном процессе: во-первых, это типология артефактов по различным критериям, как ключевого фактора организации материала для анализа; во-вторых, определение показателей, которые учитывая историко-культурный контекст, расширят результаты типологии и позволят уверенно интегрировать ее в русло культурологии как науки. Важно, что методологическая система может стать актуальной для работы с темами, связанными с несколькими художественными отраслям: музыкой, архитектурой, скульптурой, а также в исследованиях, изучающих город как художественный продукт. Интегративная природа темы требует такого же подхода, поэтому при выборе методологических инструментов важным является учитывать природу отраслей, которые объединяются в той мере, насколько это позволяет профессиональная компетенция исследователякультуролога. Научная новизна заключается в осуществлении попытки создать методологическую систему, актуальную для исследований, связанных с музыкальной иконографией в декоре архитектурных сооружений. Выводы. Научная работа по темам, которые имеют междисциплинарный характер требует детальной проработки вариантов методологического инструментария. В каждом конкретном случае выбор методов может быть продиктован уклоном в одно, либо другое научное русло. Именно поэтому создание методологической системы для исследования темы музыкальной иконографии в декоре архитектуры в контексте культурологии необходимо для логического развертывания научного поиска.

Ключевые слова: музыкальная иконография; типология; методология 